STRUKTUR BAHASA;

\title{
PEMBENTUKAN KATA DAN MORFEM SEBAgA PROSES MORFEMIS DAN MORFOFONEMIK DALAM BAHASA INDONESIA
}

\author{
Oleh: \\ SITI RUMILAH', IBNU CAHYANI ${ }^{2}$ \\ UIN Sunan Ampel Surabaya', Pegiat Komunitas Baca Rakyat ${ }^{2}$ \\ st.rumilah@gmail.com', ibnucahyani4@gmail.com²
}

\begin{abstract}
Abstrak
Pembentukan kata dan morfem dalam bahasa Indonesia merupakan fokus artikel ini. Bahasa merupakan sebuah sistem tanda dan bunyi, berarti bahwa bahasa itu sistemis sekaligus sistematis. Dengan demikian, untuk memahami suatu bahasa terlebih dahulu kita harus memahami proses pembentukan kata dan morfem sebagai bagian terkecil dari bahasa itu sendiri. Penelitian ini menggunakan metode penelitian kualitatif deskriptif. Dengan maksud untuk mengungkapkan proses pembentukan bahasa secara objektif dan apa adanya, yaitu dengan teknik menganalisa contoh kata dan morfem dalam bahasa Indonesia, selanjutnya menganalisa proses pembentukan tiap kata dan morfem tersebut. Proses pembentukan bahasa sejatinya melalui proses morfemis (a) derivasi zero, (b) afiksasi, (c) reduplikasi, (d) komposisi, (e) abrevasi, (f) derivasi balik, (g) metanalisis, (h) analogi dan (i) kombinasi proses sekaligus proses morfofonemik (a) pemunculan fonem; (b) pelesapan fonem; (c) peluluhan fonem; (d) perubahan fonem; (e) pergeseran fonem. Proses tersebut perlu dipahami sebagai bentuk kegiatan berkomunikasi untuk mengungkapkan makna, baik sebagai ide untuk mengungkap perasaan, permintaan, penolakan maupun yang lainnya. Ide tersebutlah yang kemudian disampaikan dalam bentuk kalimat yang mengandung makna.
\end{abstract}

Keyword: Bahasa, Kata, Morfem, Morfemis, Morfofonemik.

Abstract

The formation of words and morphemes in Bahasa is the focus of this article. Language is a system of signs and sounds, meaning that language is both systemic and systematic. Thus, to understand a language we must first understand the process of forming words and morphemes as the smallest part of the language itself. This study used descriptive qualitative research methods. With a view to expressing the process of forming language objectively and as is, namely by analyzing examples of words and morphemes in Indonesian, then analyzing the process of forming each word and morpheme. The process of formation of true language through morphemic processes (a) zero derivation, (b) affixation, (c) reduplication, (d) composition, (e) abrevation, (f) back-derivation, ( $g$ ) meta-analysis, (h) analogies and (i) a combination of processes as well as morphophonemic processes (a) the appearance of phonemes; (b) phoneme absorption; (c) the melting of phonemes; (d) change of phonemes; (e) phoneme shift. The process needs to be understood as a form of communication activities to express meaning, both as ideas to express feelings, requests, rejections and others. The idea is then conveyed in the form of sentences that contain meaning.

Keyword: Language, word, morpheme, morphemic, morphophonemic.

\section{PENDAHULUAN}

Kehidupan manusia selalu dikelilingi oleh bahasa. Beberapa di antara kita mendengarnya melalui radio, televisi, ungkapan orang, kata-kata yang kita baca melalui buku, simbol-simbol, surat kabar, majalah dan lain sebagainya. Hal ini telah mengafirmasi bahwa kehidupan manusia adalah tentang bahasa. Setidaknya, tidak berlebihan kiranya kita sebut, bahwa berbagai macam 
aktivitas kehidupan akan lumpuh tanpa bahasa.

Para Linguis beranggapan bahwa bahasa ialah sistem tanda (simbol) dan bunyi yang disepakati untuk dipergunakan oleh para anggota kelompok masyarakat tertentu dalam bekerjasama, berkomunikasi, dan mengidentifikasi diri. Bahasa merupakan sistem, bermakna bahwa bahasa itu sistematis sekaligus sistemis. Dengan demikian, dimaksudkan bahwa bahasa itu terdiri dari beberapa subsistem, yakni subsistem fonologi, subsistem gramatika, dan subsistem leksikon. Selanjutnya, di situlah akan bersenyawa antara dunia bunyi atau simbol dan dunia makna. Dengan demikian, karena bahasa merupakan sistem tanda berupa bunyi, dan simbol maka bahasa membentuk struktur (Kridalaksana, 2007: 6).

Sistem Bahasa

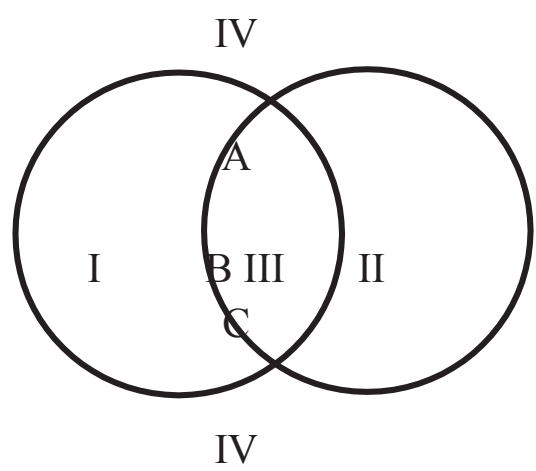

Keterangan:

I. Dunia bunyi atau simbol

II. Dunia makna

III. Struktur bahasa

IV. Pragmatik

A. Leksikon

B. Gramatika

C. Fonologi

Lebih lanjut, bahasa disebut sebagai kombinasi kata yang diatur secara sistematis. Sehingga, dapat digunakan sebagai sebuah alat komunikasi. Kata itu sendiri, merupakan bagian integral dari simbol yang dipakai oleh suatu kelompok masyarakat tertentu. Itulah sebabnya kata itu bersifat simbolis -sebagai sistem simbol—. Simbol di sini dimaksudkan sesuatu yang dapat menyimbolkan dan mewakili ide, pikiran, perasaan, benda dan tindakan secara abriter, konvensional dan representatif-interpretatif. Dimana dalam hal ini, tidak ada hubungan alamiah antara yang menyimbolkan dan yang disimbolkan. Implikasinya, berarti baik yang batiniah (perasaan, pikiran, dan atau ide), maupun yang lahiriah (benda dan tindakan) dapat disimbolkan atau diwakilkan dengan simbol (Wibowo, 2003: 3-4). Dengan demikian, karena sifat konvensional dan abriter tersebut, maka bahasa di dunia ini tidak ada yang sama antara satu dengan yang lainnya.

Senada dengan pendapat tersebut, kaum strukturalis-linguistik memberikan asumsi bahwa, kata a d a l a h sebuah tanda yang arbitrer (arbitrary sign), yang terdiri atas penanda (signifier) dan 
petanda (signified). Dalam konteks ini, istilah leksikalisasi bermakna kehadiran makna dan bentuk secara serempak sebagai "kata" -misalnya, kata "ibu", yang terdiri dari bentuk atau bunyi "ibu" dan makna (orang tua perempuan); dan gramatisasi bermakna kehadiran konsep dan bentuk gramatikal secara serempak sebagai penanda gramatik (misalnya, sufiks "s" pada kata "cars", yang bermakna lebih dari satu).

Di lain pihak, dalam paradigma bahas a sebagai cermin masyarakat atau cermin budaya, sebagaimana diungkap Sapir dan dipertegas pendapat Francis- bahasa memiliki arti ...is a system of arbitrary vocal or visual symbols used by people of a given culture as a means to carry on their daily affairs, (...sistem verbal atau visual bersifat manasuka, yang digunakan sekelompok penutur dengan budaya tertentu, sebagai alat komunikasi dalam kehidupan mereka sehari-hari) (Sapir, 1921: 8). Jelas kiranya dalam pandangan tersebut, bahwa bahasa merupakan bagian dari entitas budaya. Sedangkan budaya sendiri memungkinkan bersifat khusus dan muncul secara jelas melalui ekspresi bahasa masyarakat tertentu.

Secara garis besar, -meminjam istilah Akmajian dkk- ilmu linguistik (ilmu tentang bahasa) dibagi menjadi dua konteks paradigma besar, yakni macrolinguistic yang mempelajari linguistik dan hubungannya dengan ilmu- ilmu di luar linguistik (semisal antropologi, sosial, budaya dan psikologi) dan microlinguistic yang mempelajari bidang-bidang bahasa yang bertalian dengan bahasa itu sendiri (fonologi, morfologi, sintaksis, semantik dan pragmatik) (Akmajian, 2001: 13-14).

\section{METODE PENELITIAN}

Penelitian ini menggunakan metode kualitatif deskriptif dengan maksud memahamami fenomena kebahasan secara objektif dan apa adanya. Artinya, secara spesifik penelitian ini berusaha melakukan analisa terhadap pembentukan kata melalui proses morfemis dan morfofenemik. Pendekatan yang digunakan dalam penelitian ini adalah pendekatan struktural. Pendekatan struktural dimaksudkan untuk melakukan penelusuran bentuk (form) dari gejala yang ada bersumber dari contoh kalimat atau kata dalam bahasa Indonesia (Zaim, 2014: 15). Contoh kata atau kalimat dalam bahasa Indonesia tersebut selanjutnya dilakukan analisa untuk menjelaskan proses dari pembentukan dari tiap - tiap kata sehinga terbentuk menjadi sebuah sistem bahasa. Penelitian ini menggunakan teknik analisa Distribusi Bagi Unsur Langsung (BLU). Teknik ini dimaksudkan dengan membagi satuan lingual kata dan kalimat menjadi beberapa unsur dan bagian (Zaim, 2014: 106). Unsur dan bagian ini lah yang kemudian dilakukan analisis melalui proses morfemis dan morfofonemik.

\section{HASIL PENELITIAN DAN PEMBAHASAN}

\section{Kelindan antara Morfem dan Kata}

Berbahasa (berbicara atau menulis) sejatinya adalah hendak mengungkapkan makna dalam bentuk gagasan, perasaan, permintaan, dan lain sebagainya. Gagasan tersebut kemudian kita sampaikan dalam bentuk kalimat- kalimat, di mana kalimat tersusun atas beberapa kata yang mengandung makna dan selanjutnya akan membentuk makna, Suhardi (2015: 43). Agar lebih 
jelas, mari kita perhatikan contoh kalimat "Ibu memasak nasi".

Apabila kita potong kalimat di atas dalam tiap-tiap bagiannya yang lebih kecil, dan kita pisahkan tiap-tiap bagian tersebut sehingga setiap bagian itu tampak berdiri sendiri. Maka kita akan dapati bahwa dalam tiap-tiap bagian tersebut mempunyai makna. Bagian terkecil dalam suatu kalimat yang memilki makna dan mampu berdiri sendiri, itulah yang disebut sebagai kata. Jadi dalam contoh kalimat di atas terdiri atas tiga kata, yaitu: "Ibu”, "memasak", dan —nasi".

Selanjutnya, apabila pemotongan bagian-bagian itu kita lanjutkan terhadap tiap-tiap kata, akan kita dapatkan beberapa kata yang masih dapat dipotong dalam potongan yang lebih kecil, yang tentunya dalam pemisahanan tersebut tetap memiliki makna. Namun, ada juga kata yang sudah tidak dapat dipisah lagi menjadi bagian yang lebih kecil yang masih memiliki makna.

Kata "memasak" dapat kita pisah menjadi "me" dan "masak" yang kedua bagian tersebut masih tetap mimiliki makna. Tetapi apabila kita potong kata "nasi" menjadi dua bagian "na" dan "si", maka kita tidak akan dapatkan makna dalam bagian-bagian tersebut. Dengan demikian kata "nasi" memang sudah tidak dapat dipotong lagi menjadi bagian lebih kecil yang memiliki makna. Bentuk bagian dari potongan dalam suatu kata, seperti "me” dan " masak" disebut sebagai "morfem". Maka, kata "memasak" sebenarnya terdiri atas dua morfem "me" dan "masak" yang mengalami inkorporisasi sehingga membentuk satu kata tunggal "memasak", sedangkan kata "nasi" terdiri dari satu morfem saja.

Sejak Bloomfield dengan bukunya "Language" yang pertama kali terbit pada tahun 1933 dan karangannya yang terbit dalam majalah profesi sebelumnya "A Set Postulates for the Science of Language", 1920), perhatian para linguistik deskriptif mulai tertuju pada morfem sebagai unit bahasa dalam analisis bahasa. Bloomfield (1984: 161), menawarkan sebuah definisi tentang morfem sebagai berikut: "a linguistic form which bears no partial phonetic-semantic resemblance to any other from, is a simple form or a morpheme". Satu bentuk bahasa yang sebagiannya tidak mirip dengan bentuk lainnya, baik bunyi maupun makna, adalah sebuah bentuk tunggal bahasa atau morfem.

Sebagaimana disebutkan di atas, dalam ruang kajian morfologi dikenal sebuah unsur dasar atau satuan terkecil dalam lokus pengamatannya. Di mana satuan unsur terkecil itu disebut sebagai morfem. Sebagai satuan gramatikal, morfem membentuk satuan yang lebih besar dan mempunyai makna. Sebagai satuan terkecil, morfem tidak dapat dipecah menjadi bagian-bagian yang lebih kecil, yang masing-masing bagian tersebut mengandung makna. Kata terkecil itu tersebut menyiratkan adanya satuan gramatikal yang lebih besar dari morfem. Inilah yang dalam ilmu bahasa disebut sebagai kata, frasa, klausa dan kalimat. dengan demikian, morfem menjadi bagian pembentuk atau konstituen satuan-satuan gramatikal yang lebih besar tersebut, (Kushartanti, 2007: 144).

Kata disusun oleh satu atau beberapa morfem. kata bermorfem satu disebut sebagai kata monomorfemis, sedangkan kata bermorfem lebih dari satu disebut kata polimorfemis. Dalam kalimat "Anto berlari menuju barat", misalnya, terdapat dua monomorfemis, yaitu "Anto", dan "timur", dan dua kata polimorfemis, "berlari" dan "menuju". Penggolongan kata menjadi monomorfemis dan polimorfemis sejatinya hanya terletak pada jumlah satuan morfem yang menyusun kata (Kushartanti, 2007: 151). 
Charles F. Hockett (2007: 15), memberikan definisi dan metode penemuan morfem dengan cara yang lebih sederhana. Pada tataran definisi Hockett memberikan pengertian "morphemes are the smallest individually meaningful elements in the uttarances of a language" morfem adalah unsur-unsur terkecil yang masing- masing mempunyai makna dalam tutur sebuah bahasa. Sedangkan pada ruang aplikatif cara menemukan morfem, Hockett, memberikan langkah awal dengan mengajukan pertanyaan sebagai berikut: Apakah bentuk-bentuk dalam tutur bahasa dapat dipisah-pisah atas bentuk-bentuk yang lebih kecil dan bentuk itu dapat dikemukakan kembali dalam tutur lain dengan makna lebih kurang sama atau mirip sama? Jika jawabannya "ya" maka itulah morfem-morfem.

Morfem yang dapat berdiri sendiri seperti kata "ibu", "masak", dan "nasi" -seperti contoh yang telah disebutkan di atas- disebut sebagai morfem bebas, sedangkan morfem yang melekat pada bentuk morfem lain seperti "me" dalam kata "memasak" disebut sebagai morfem terikat. Terdapat juga satu morfem yang disebut sebagai "morfem unik", yaitu suatu morfem yang hanya dapat berkombinasi dengan satu-satuan morfem tertentu.

Sebagaimana disebutkan sebelumnya, morfem dapat berupa kata, tetapi sebuah kata dapat berwujud satu morfem atau lebih. Morfem yang sekaligus juga kata adalah morfem bebas (monomorfemis), sedangkan kata yang terdiri atas dua morfem atau lebih merupakan gabungan morfem-morfem bebas dan morfem terikat -mungkin juga gabungan morfem bebas dan morfem bebas- (polimorfemis).

Morfem "me" dalam kata "memasak" bentuknya bisa bervariasi mengikuti fonem (bunyi) pertama yang dilekatinya. Dalam pemakaipannya morfem "me" bisa berubaha menjadi "mem" (membaca), "men" (mendengar), "meng" (menghitung), "meny" (menyikat), dan "menge" (mengetahui). Anggota suatu morfem yang wujudnya berbeda, tetapi mempunyai fungsi dan makna yang sama dinamakan "alomorf" (Wiyanto, 2012: 2).

Berdasarkan tempat terikatnya, pada sebuah morfem dasar, morfem terikat (dalam proses afiksasi) dapat dibagi menjadi lima jenis, yaitu awalan (prefiks), sisipan (infiks), akhiran (sufiks), gabungan awalan-akhiran (konfiks) dan imbuhan gabungan (simulfiks). Sementara itu, berdasarkan fungsinya morfem terikat dapat dibedakan mendaji tiga jenis, yaitu, morfem pembentuk kata kerja, morfem pembentuk kata benda, dan morfem pembentuk kata sifat.

\section{Proses Morfemis}

Pembentukan kata dalam Bahasa Indonesia merupakan sistem alamiah yang telah berhasil untuk mengembangkan makna leksem. Dengan demikian, Pembentukan kata itu telah memekarkan konsep penutur bahasa mengenai dirinya dan alam sekitarnya. Dalam setiap bahasa terdapat sejumlah satuan leksikal yang abstrak yang mendasari berbagai bentuk inflektif sebuaf kata. Satuan leksikal itu disebut sebagai leksem (lexeme). Dalam bahasa Inggris, misalnya, kata sleep, slept, sleeps, dan sleeping adalah bentuk kata yang berasal dari satuan dasar yang abstrak sleep. Jadi, sleep adalah leksem yang dapat diubah menjadi slept, sleeps, dan sleeping, (Arifin dan Junaiyah, 2009: 8). Perubahan kata dari kata dasar menjadi beberapa kata -dalam proses morfemis- tersebut disebut sebagai derivasi. 
Dalam beberapa bahasa di dunia, proses morfemis -meminjam istilah Kushartati dkkdibagi menjadi dua bentuk, yaitu infleksi dan derivasi. Infleksi mengubah bentuk suatu kata untuk menetapkan hubungannya dengan kata-kata lain dalam kalimat atau dalam menandai hubungan sintaktik. Sementara itu, proses derivasi mengubah suatu kata menjadi kata baru. Kata baru itu pada umumnya lain kelas atau jenisnya dengan kata yang belum mengalami derivasi dalam proses infleksi perubahan kelas kata itu tidak terjadi-, (Kushartanti dkk, 2007: 152). Senada dengan pendapat tersebut, Bauer (1988:12), dalam buku Introducing Linguistic Morphology, menyatakan bahwa proses morfemis dibagi atas morfemis derivasional dan morfemis infleksional. Derivasi menjadi bagian dari leksis karena menyediakan leksem- leksem baru dan infleksi merupakan bagian dalam sintaksis karena bersifat melengkapi bentuk-bentuk leksem.

Infleksi berkaitan dengan kaidah-kaidah sintaktik yang dapat diramalkan (predictable), otomatis (automatic), sistematik, bersifat tetap/konsisten, dan tidak mengubah identitas leksikal, sedangkan derivasi lebih bersifat tidak bisa diramalkan, berdasarkan kaidah sintaktik, tidak otomatis, tidak sistematik, bersifat optional/sporadis, serta mengubah identitas leksikal, (Katamba, 1993: 92-100). Lebih lanjut, Samsuri (1982: 198) menyatakan bahwa derivasi ialah konstruksi yang berbeda distribusinya daripada dasarnya, sedangkan infleksi adalah konstruksi yang menduduki distribusi yang sama dengan dasarnya. Dalam bahasa-bahasa Eropa, (utamanya Inggris), pengertian derivasi dan infleksi dapat dikenakan secara konsisten. Misalnya: books (dari book), stop, stopped, stopping (stop); prettier, prettiest (pretty); sebagai contoh infleksi. Sedangkan derivasi dicontohkan: runner (run), beautify (beauty). Semua bentuk seperti book, jika mendapat sufiks -s (plural), merupakan infleksi, seperti wall-walls, chair-chairs, dan sebagainya. Namun, di dalam bahasa Indonesia tidaklah demikian, karena sistem afiks bahasa Indonesia berbeda dengan bahasa Inggris. Contohnya, "menggunting" termasuk derivasi, sedangkan "membaca" dan "mendengar" adalah infleksi. Oleh sebab itu masih merupakan persoalan, apakah pengertian infleksi dan derivasi dapat diterapkan secara konsisten di dalam bahasa Indonesia.

Secara sederhana, suatu leksem dapat dibentuk menjadi sebuah kata melalui proses morfemis. Dengan demikian, proses morfemis (morfological process) adalah suatu proses yang mengubah leksem menjadi kata. Dapat dikatakan bahwa leksem merupakan input (masukan/ kata dasar), dan kata merupakan output (keluaran/hasil/turunan). Dalam beberapa istilah tentang kajian bahasa proses morfemis juga disebut sebagai pembentukan kata. Beberapa literatur linguistik menyebutkan bahwa proses morfemis disebut juga sebagai proses morfologis atau proses morfologik. Proses morfemis ialah pembentukan kata dengan menghubungkan morfem yang satu dengan morfem yang lain. Salah satu wujud dari proses morfemis ialah penggabungan morfem dasar dengan morfem afiks. Setiap bahasa mempunyai peranti pembentukan kata untuk mengembangkan sebuah konsep. Dalam proses pembentukan kata, leksem sebagai unsur leksikon diolah menjadi kata melalui proses morfemis.

Sekurang-kurangnya, dalam bahasa Indonesia terdapat sembilan jenis proses morfemis. Sembilan proses morfemis dalam bahasa Indonesia antara lain sebagai berikut: Derivasi Zero, Afiksasi, Reduplikasi, Komposisi, Abrevasi, Derivasi balik, Metanalisis, Analogi dan Kombinasi Proses (Arifin dan Junaiyah, 2009: 9). Kesembilan proses morfemis itu menjelaskan terjadinya suatu kata secara alamiah dalam bahasa Indonesia. Proses pembentukan kata dalam bahasa Indonesia merupakan siklus leksem yang sudah mengalami gramatikalisasi, setelah menjadi kata, 
dapat masuk kembali leksikon, melalui proses leksikalisasi. Lebih dari itu, frasa yang merupakan gabungan kata, bukan sekedar gabungan leksem, melainkan bisa mengalami proses pembentukan kata. Singkatnya, proses pembentukan kata dalam bahasa Indonesia merupakan sistem terpadu -walaupun terdapat rumpang di sana-sini-.

\section{Derivasi Zero}

Derivasi zero adalah proses pembentukan kata yang mengubah leksem tunggal menjadi kata tunggal. Leksem "tidur" yang berupa leksem tunggal, misalnya, dapat berubah menjadi kata tunggal "tidur" melalui proses morfemis derivasi zero. selama kita menyebut kata "tidur" sebagai kata dasar. Padahal, sebelum menjadi kata, "tidur" adalah sebuah leksem. Dengan demikian, kata-kata dasar yang lain, seperti rumah, tanah, air, sungai, laut, langit dan lain sebagainya, sebelum melalui proses morfemis derivasi zero menjadi kata, bentukbentuk tersebut adalah leksem (Arifin dan Junaiyah, 2009: 10).

\section{Gambar 3.1 \\ Proses Derivasi Zero}

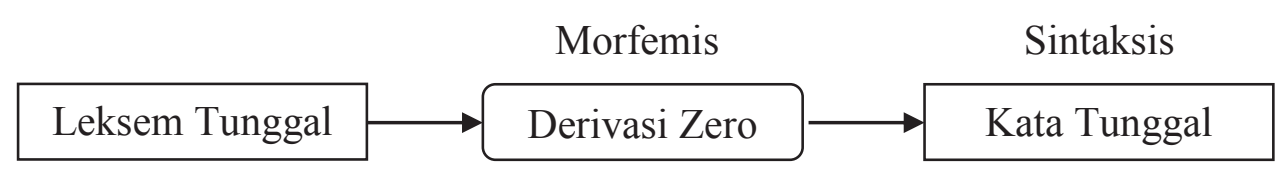

\section{Afiksasi}

Afikasi adalah proses atau hasil penambahan (perangkaian) afiks pada akar, dasar atau alas kata. Dalam proses ini, leksem mengalami perubahan bentuk menjadi kategori tertentu sehingga berstatus kata dan sedikit banyak berubah maknanya (Ingguoe, 2015:38). Proses afiksasi merupakan proses yang paling umum dalam bahasa. Proses afiksasi terjadi apabila morfem terikat dibubuhkan atau diletakkan pada sebuah morfem bebas secara urutan lurus (Parera, 2007: 18). Sebagaimana telah disebutkan sebelumnya, berdasarkan letak distribusi afiks, proses afiksasi dapat dibagi menjadi lima jenis, yaitu awalan (prefiks), sisipan (infiks), akhiran (sufiks), gabungan awalan-akhiran (konfiks) dan imbuhan gabungan (simulfiks).

\section{a. Awalan (Prefiks)}

Secara etimologi prefiks merupakan serapan dari bahasa Inggris (prefix) yang merupakan gabungan dari kata "pre" (sebelum) dan "fix" (membubuhi). Prefiksasi merupakan proses perangkaian afiks di awal dasar (bisa kata dasar atau turunan) (Wedhawati et al, 2006:41). Dengan demikian, Prefiks merupakan imbuhan yang diletakkan di awal dasar. Dalam bahasa Indonesia terdapat beberapa prefiks, antara lain ber, per, me, di, ter, $k e$, dan se, seperti dalam kata berikut: 
Tabel 3.1

Contoh Imbuhan Awalan (Prefiks)

\begin{tabular}{|c|c|c|c|}
\hline No & Awalan & Leksem & Sintaksis \\
\hline 1 & Ber & Tanya & Bertanya \\
\hline 2 & Ber & Kerja & Bekerja \\
\hline 3 & Per & Kerja & Pekerja \\
\hline 4 & Per & Tulis & Penulis \\
\hline 5 & Per & Asuh & Pengasuh \\
\hline 6 & Me & Lihat & Melihat \\
\hline 7 & Me & Tulis & Menulis \\
\hline 8 & Me & Baca & Membaca \\
\hline 9 & Me & Sapu & Menyapu \\
\hline 10 & Di & Lihat & Dilihat \\
\hline 11 & Di & Pukul & Dipukul \\
\hline 12 & Ter & Lihat & Telihat \\
\hline 13 & Ter & Jaga & Terjaga \\
\hline 14 & Ke & Satu & Kesatu \\
\hline 15 & Ke & Dua & Kedua \\
\hline 16 & Se & Rasa & Serasa \\
\hline 17 & Se & Manis & Semanis \\
\hline
\end{tabular}

\section{b. Sisipan (Infiks)}

Infiks merupakan Imbuhan yang secara struktural diletakkan di tengah sebuah bentuk dasar, yaitu antara konsonan yang mengawali sebuah kata dengan vokal berikutnya (Tukan, 2006: 33). Sehingga, proses infiksasi merupakan proses perangkaian afiks di tengah dasar. Bahasa Indonesia, secara umum memiliki empat bentuk infiks, yaitu em, el, in dan er.

Tabel 3.2

\section{Contoh Imbuhan Sisipan (Infiks)}

\begin{tabular}{|c|c|c|c|}
\hline No & Leksem & Sisipan & Sintaksis \\
\hline 1 & Gunung & em & Gemunung \\
\hline 2 & Patuk & el & Pelatuk \\
\hline 3 & Kerja & In & Kinerja \\
\hline 4 & Gigi & Er & Gerigi \\
\hline
\end{tabular}

\section{c. Akhiran (Sufiks)}

Sufiks adalah afiks yang dibubuhkan diakhir dasar. Dalam bahasa Indonesia terdapat berbagai bentuk sufiks, anrara lain, $i$, kan, an, wan, wati, man, wi, nya, nda, if, dan or. 
Tabel 3.3

Contoh Imbuhan Akhiran (Sufiks)

\begin{tabular}{|c|c|c|c|}
\hline No & Leksem & Akhiran & Sintaksis \\
\hline 1 & Islam & I & Islami \\
\hline 2 & Pukul & Kan & Pukulkan \\
\hline 3 & Makan & An & Makanan \\
\hline 4 & Harta & Wan & Hartawan \\
\hline 5 & Karya & Wati & Karyawati \\
\hline 6 & Seni & Man & Seniman \\
\hline 7 & Dunia & Wi & Duniawi \\
\hline 8 & Hebat & Nya & Hebatnya \\
\hline 9 & Adik & Nda & Adinda \\
\hline 10 & Sport & If & Sportif \\
\hline 11 & Senat & Or & Senator \\
\hline
\end{tabular}

Dalam bahasa Indonesia juga dikenal sufiks serapan dari beberapa bahasa asing, seperti, iah (alamiah), isme (kapitalisme), is (biologis), isasi (naturalisasi),asme (sarkasme), in (hadirin)

\section{d. Gabungan Awalan Akhiran (Konfiks)}

Konfiks merupakan imbuhan yang terdiri atas dua bagian yang diletakan pada awal dan akhir kata dasar atau bentuk dasar secara sejajar. Dengan demikian, dapat dikatakan bahwa proses konfiksasi adalah perangkaian prefiks (awalan) dan sufiks (akhiran) secara bersamaan dalam suatu kata dasar atau bentuk dasar tertentu (Tukan, 2006: 33). Dalam pembahasan ini, konfiks perlu kita bicarakan secara khusus, karena dalam prosesnya konfiksasi mempunyai bentuk yang berbeda dengan afiks-afiks yang lain. Perbedaannya, konfiks merupakan bentuk terbelah, yaitu sebagian berada di depan kata dasar dan sebagian berada di belakang kata dasar. Secara sekilas memang seperti dua afiks, akan tetapi sebenarnya tetap merupakan satu afiks (Wiyanto, 2012: 6).

Misalnya, afiks "ber-an" pada kata "berhamburan", di sini afiks "ber-an" merupakan konfiks karena melekat bersama-sama pada kata dasar dan bersama-sama pula menjalankan fungsinya. Hal ini akan tampak nyata bedanya bila dibandingkan dengan afiks "ber-" dan "-an" pada kata "berpakaian". Afiks "ber-" dan "-an" bukanlah konfiks, karena tidak merangkai secara bersama-sama dan tidak bersama-sama mendukung suatu fungsi. Afiks "-an" terlebih dahulu melekat pada kata "pakai" menjadi "pakaian" yang secara gramatis sendiri membentuk kata benda, kemudian afiks "ber-" melekat pada kata "pakaian" menjadi "berpakaian", yang juga mempunyai fungsi gramatis sendiri yaitu membentuk kata kerja. Sebaliknya, konfiks "ber-an" bersama-sama melekat pada kata "hambur" menjadi "berhamburan" (Wiyanto, 2012: 6-7). 
Tabel 3.4

Contoh Imbuhan Gabungan Awalan Akhiran (Konfiks)

\begin{tabular}{|c|c|c|c|}
\hline No & Leksem & Konfiks & Sintaksis \\
\hline 1 & Mati & Ke-an & Kematian \\
\hline 2 & Hambur & Ber-an & Berhamburan \\
\hline 3 & Ambil & Peng-an & Pengambilan \\
\hline 4 & Baik-baik & Se-an & Sebaik-baiknya \\
\hline 5 & Juang & Per-an & Perjuangan \\
\hline 6 & Manusia & Ke-an & Kemanusiaan \\
\hline
\end{tabular}

\section{e. Imbuhan Gabungan (Simulfiks)}

Simulfiks atau imbuhan gabung adalah dua imbuhan atau lebih yang ditambahkan pada kata dasar tidak sekaligus, tetapi secara bertahap. Dengan demikian, afiks gabungan berbeda dengan konfiks. Hal ini perlu kita perhatikan karena bentuk keduanya mirip. Namun, ada beberapa perbedaan nyata, yaitu konfiks melekat bersama-sama pada kata dasar. Misalnya, "ke-an" dalam "kemanusiaan". Konfiks "ke-an" itu melekat bersama-sama dalam satu proses. Sebaliknya, afiks gabungan tidak melekat bersama-sama. Misalnya dalam kata "dimasukkan", sufiks "-kan" melekat dulu pada kata "masuk" menjadi "masukkan", kemudian prefiks "di-" melekat pada masukkan menjadi "dimasukkan". Jadi, dalam kata "dimasukkan" terdapat dua afiks yang bergabung, yaitu prefik "di-" dan sufiks "-kan", Wiyanto (2012: 8).

Tidak sembarang prefiks dapat bergabung dengan sembarang sufiks. Adapun beberapa contoh afiks yang dapat bergabung secara berurutan hingga membentuk proses simulfiksasi adalah sebagai berikut:

Tabel 3.5

Contoh Imbuhan Gabungan (Simulfiks)

\begin{tabular}{|c|c|c|c|}
\hline No & Leksem & Simulfiks & Sintaksis \\
\hline 1 & Hilang & Meng-kan & Menghilangkan \\
\hline 2 & Hadir & Meng-i & Menghadiri \\
\hline 3 & Main & Per-kan & Permainkan \\
\hline 4 & Lengkap & Per-i & Perlengkapi \\
\hline 5 & Dasar & Ber-kan & Berdasarkan \\
\hline 6 & Selesai & Ter-kan & Terselesaikan \\
\hline 7 & Penuh & Ter-i & Terpenuhi \\
\hline 8 & Tentu & Di-kan & Ditentukan \\
\hline 9 & Datang & Di-i & Didatangi \\
\hline
\end{tabular}




\section{Reduplikasi}

Dalam tataran morfologi bahasa Indonesia, sampai sekarang reduplikasi belum mendapat deskripsi yang secara eksplisit dinyatakan oleh para linguis. Sehingga, pemerian atau penggolongan jenis reduplikasi dalam bahasa Indonesia pun berbeda-beda, dengan kriteria pemerian yang tidak disebutkan. Dalam berbagai istilahnya, reduplikasi disebut juga bentuk ulang, Keraf (1991), kata ulang, Keraf (1984) dan proses pengulangan Ramlan (1979).

Reduplikasi merupakan suatu proses dan hasil pengulangan satuan bahasa sebagai alat fonologis atau gramatikal, sehingga selanjutnya dapat ditemui reduplikasi fonologis dan reduplikasi gramatikal -dengan pengertian reduplikasi gramatikal mencakup reduplikasi morfemis atau reduplikasi morfologis, dan reduplikasi sintaksis-. Namun, ada juga yang mengelompokkan begitu saja reduplikasi menjadi reduplikasi fonologis reduplikasi morfemis dan reduplikasi sintaksis (Kridalaksana, 1982: 13). Reduplikasi fonologis merupakan peristiwa reduplikasi yang dapat berupa perulangan suku, atau suku kata sebagai bagian kata, bentuk dasar dari reduplikasi fonologis ini secara deskriptif sinkronik tidak dapat ditemukan dalam bahasa yang bersangkutan. Seperti terlihat dalam beberapa kata sebagai berikut; papa, mama, kuku, biri-biri, kura-kura, kupu-kupu. Reduplikasi seperti ini oleh para ahli bahasa Indonesia disebut juga sebagai reduplikasi semu (Samsuri, 1988: 91).

Di lain pihak, reduplikasi morfologi (reduplikasi morfemis) lebih mengacu pada persoalan input yang berupa morfem. Konsep reduplikasi morfologi pada hakikatnya memiliki kesamaan di antara para ahli bahasa Indonesia, hanya saja dalam menyebut bentuk dasar dari bentuk ulang dijumpai berbagai macam penyebutan yang berlainan.

Gorys Keraf (1989: 149), (dalam pengertian reduplikasi morfologis) memberikan batasan bahwa reduplikasi merupakan bentuk gramatikal yang berwujud penggandaan sebagian atau seluruh bentuk dasar sebuah kata. Hal senada diungkap Ramlan (2009: 38), bahwa proses pengulangan atau reduplikasi merupakan pengulangan bentuk kata, baik seluruhnya maupun sebagian, baik dengan variasi fonem maupun tidak. Hasil perulangan itu berupa kata, dan bentuk yang diulang merupakan bentuk dasar.

Dari dua batasan tersebut, jelas kiranya bahwa reduplikasi merupakan gejala repetisi suatu bentuk kata. Adapun bentuk yang diulang tersebut, rupanya bermacam-macam, dan cara pengulangannya dapat secara utuh dapat pula hanya sebagian, dan pula akan ditemui kemungkinan dijumpai variasi fonem. Proses reduplikasi selanjutnya memunculkan sebuah kata turunan atau kata kompleks dari kata dasar.

\section{Gambar 3.2 Proses Reduplikasi}

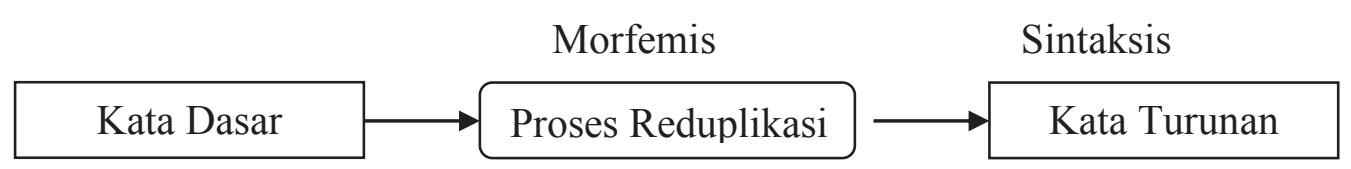

Reduplikasi morfologis harus dibedakan dengan kata yang diulang, karena kata yang diulang tidak akan menghasilkan kata, tetapi menghasilkan kata-kata. Kata repetisi tersebut -yang menghasilkan kata-kata- sering kita jumpai dalam konteks tertentu, seperti berbahasa 
yang dilakukan oleh seorang penjual dalam menjajakan barang dagangannya, jagung, jagung, tahu,tahu.

Beberapa bahasa, memungkinkan bentuk dasar dalam proses reduplikasi merupakan bentuk turunan atau bentuk kompleks. Dalam artian, bentuk dasar ini terlebih dahulu telah dikenakan proses morfologi lain (afiksasi dll sebagainya) sehingga menjadi kata turunan, selanjutnya menjadi unsur proses morfologi lagi untuk membentuk kata "baru" yang lain sehingga terjadi rekursi. Kridalaksana (2007: 14), memberikan batasan tentang kembalinya kata menjadi unsur leksikal itu disebut sebagai leksikalisasi, dan sebaliknya berubahnya leksem menjadi kata disebut sebagai gramatikalisasi. Misalnya, bentuk "berjalan-jalan" (diasumsikan bentuk dasarnya berjalan) dapat ditunjukkan prosesnya:

a. Proses I : prefiksasi ber-terhadap bentuk jalan menjadi berjalan

b. Proses II : leksikalisasi berjalan menjadi unsur leksikal yang biasanya disebut leksem

c. Proses III : reduplikasi bentuk berjalan menjadi berjalan-jalan.

Bentuk orang-orang dapat ditunjukkan prosesnya:

a. Proses I : gramatikalisasi leksem orang menjadi kata orang.

b. Poses II : leksikalisasi orang menjadi leksem orang.

c. Proses III : reduplikasi orang menjadi orang-orang

Reduplikasi sintaksis merupakan reduplikasi gramatikal yang inputnya berupa leksem (ada yang menyebut morfem), dan hasilnya berupa klausa. Persoalannya kalausa di sini bukan dalam arti bentuk, melainkan dalam semantik. Chaer (2009: 268), memberikan pandangan, jika dilihat dari hasil pengulangannya reduplikasi dapat dibedakan menjadi empat jenis. Antara lain; kata ulang utuh/murni, kata ulang berubah bunyi, kata ulang sebagian, dan kata ulang berimbuhan.

1) Kata ulang utuh/murni (dwilingga) adalah reduplikasi yang bagian perulangannya sama seperti dasar yang diulannya. Seperti:

Jalan : jalan-jalan

Minum $\quad$ : minum-minum

2) Kata ulang berubah bunyi (dwilingga salin suara) merupakan reduplikasi yang bagian perulangannya berubah bunyi baik vokal maupun konsonannya.

Lirik : : larak-lirik

Serba : serba-serbi

Sayur : sayur-mayur

3) Kata ulang sebagian (dwipurwa) adalah reduplikasi yang perulangannya hanya menampilkan suku kata awalnya saja dan biasanya disertai dengan perubahan vokal pada suku kata awal.

Tanaman : tetanaman 


\section{Tangga : tetangga}

4) Kata ulang berimbuhan (dwilingga berimbuhan) adalah reduplikasi yang diawali dengan proses afiksasi (pengimbuhan) yang setelahnya kata dasar tersebut baru diulang, atau dapat pula terjadi sebaliknya sehingga kata dasar tersebut terlebih dahulu direduplikasi setelahnya baru dipasangkan afiksasi, dan juga secara bersamaan antara reduplikasi dan afiksasi.

$$
\begin{array}{lll}
\text { Atur }+ \text { "per-an" } & \text { :peraturan } & \text { :peraturan-peraturan } \\
\text { Balik } & \text { : bolak-balik }+ \text { mem } & \text { : membolak-balik }
\end{array}
$$

\section{Komposisi}

Komposisi atau pemajemukan adalah penggabungan dua kata yang menimbulkan suatu kata baru (Ramlan, 2009; 86). Lebih lanjut, Chaer (2008: 209) memberikan pandangan bahwa komposisi adalah proses penggabungan dasar dengan dasar -biasanya berupa akar maupun bentuk berimbuhan- untuk mewadahi suatu konsep yang belum tertampung dalam sebuah kata. Dalam pandangan tersebut, Chaer memberikan pandangan bahwa komposisi dapat dibedakan menjadi lima macam, yaitu;

a. Komposisi yang menampung konsep-konsep yang digabungkan sederajat, sehingga bentuk komposisinya yang koordinatif. Contoh: baca tulis, makan minum, kaya miskin.

b. Komposisi yang menampung konsep-konsep yang digabung tidak sederajat, sehingga melahirkan komposisi yang subordinatif. Contoh: sate ayam, makan malam, sate kambing.

c. Komposisi yang menghasilkan istilah, yakni yang maknanya sudah pasti, sudah tentu, sekalipun bebas dari konteks kalimatnya sebagai istilah yang digunakan dalam bidang ilmu atau kegiatan tertentu. Contohnya: tolak peluru, angkat besi, terjun payung.

d. Komposisi pembentuk idiom, yakni penggabungan dasar dengan dasar yang menghasilkan makna idiomatik, yaitu makna yang tidak dapat diprediksi secara leksikal maupun gramatikal. Contoh : memeras keringat (bekerja keras).

e. Komposisi yang menghasilkan nama, yakni yang mengacu pada sebuah wujud dalam dunia nyata. Contohnya : stasiun gambir, selat sunda.

\section{Abrevasi}

Kridalaksana (2007: 159), memberikan definisi bahwa abreviasi adalah proses penanggalan beberapa bagian leksem atau kombinasi leksem sehingga jadilah bentuk baru yang berstatus kata. Dalam proses ini, leksem atau gabungan leksem menjadi kata kompleks atau akronim atau singkatan dengan pelbagai abreviasi, yaitu dengan pemenggalan, kontraksi, akronimi, dan penyingkatan.

a. Singkatan, merupakan salah satu hasil proses pemendekan yang berupa huruf atau gabungan huruf, baik yang cara membacanya dieja huruf demi huruf maupun yang tidak. Contoh: Kuliah Kerja Nyata (KKN), Sekolah Dasar (SD).

b. Penggalan, yaitu proses pemendekan yang mengekalkan salah satu bagian dari leksem. Contoh: Profesor (Prof), Ibu (Bu). 
c. Akronim, merupakan proses pemendekan yang menggabungkan huruf atau suku kata atau bagian lain yang ditulis dan dilafalkan sebagai sebuah kata yang sedikit banyak memenuhi kaidah fonotaktik bahasa Indonesia seperti, SIM (Surat Izin Mengemudi), IKIP (Institut Keguruan dan Ilmu Pendidikan).

d. Kontraksi, yaitu proses pemendekan yang meringkaskan leksem dasar atau gabungan leksem seperti, takkan (tidak akan), rudal (peluru kendali), sendratari (seni drama tari).

e. Lambang huruf, yaitu proses pemendekan yang menghasilkan satu huruf atau lebih yang menggambarkan konsep dasar kuantitas, satuan atau unsur, seperti cm (centimeter), $\mathrm{kg}$ (kilo gram).

\section{Derivasi Balik}

Derivasi balik (back derivation) merupakan proses yang dapat menjelaskan mengapa "dipungkiri" padahal kata tersebut berasal dari kata dasar "mungkir" dan tidak menjadi "dimungkiri" (Arifin dan Junaiyah, 2009: 15). Gejala tersebut -derivasi terbalik- merupakan proses pembentukan kata berdasarkan pola-pola yang ada, tanpa mengenal atau mempertimbangkan unsur-unsurnya. Akibatnya, timbul bentuk yang secara historis tidak dapat diramalkan (Kridalaksana, 2007: 181).

Agar lebih jelas perlu kita perhatikan dua contoh yang diberikan Kridalaksana sebagaimana berikut: "ketik" dalam "diketik" yang dipakai karena dikira merupakan padanan pasif dari "mengetik". Padahal, bentuk "mengetik" muncul bukan karena peluluhan fonem /k/, melainkan karena proses menyisipan " $e$ " pada bentuk dasar ekasuku "tik" (mungkin merupakan onomatope), sama seperti pada pembentukan kata "mengebom" dari "bom" Kridalaksana (2007: 181).

\section{Metanalisis}

Metanalisis merupakan proses yang dapat menjelaskan bentuk-bentuk dengan "pramu" dalam "pramugari", "pramusaji", "pramuniaga" atau bentuk yang secara historis salah, seperti bentuk "kembara", yang seharusnya "embara" dan "mupakat" yang seharusnya "mufakat". Dengan demikian, pembentukan kata seperti "tunakarya", "tunasusila", "tunanetra", "tunawisma", "tunadaksa", dan lain sebagainya adalah bentuk metanalisis (Arifin dan Junaiyah, 2009: 15).

\section{Analogi}

Analogi dalam ilmu bahasa adalah persamaan antar bentuk yang menjadi dasar terjadinya bentuk-bentuk yang lain. Analogi merupakan salah satu proses morfologi di mana dalam analogi, pembentukan kata baru dari kata yang telah ada. Contohnya pada kata dewadewi, putra-putri, pemuda-pemudi, dan karyawan-karyawati.

Pembentukan kata melalui proses morfemis analogi dilakukan dengan bertolak dari bentuk yang sudah ada dalam bahasa Indonesia. Di antara analogi untuk pembentukan kata 
adalah penggunaan awalan "pe-" yang bermakna "yang di-" sebagai kontras "yang meng-" dan "pe-“ yang bermakna "yang ber-“. Misalnya,dalam bahasa Indonesia, terdapat kata "pesuruh" yang berarti "orang yang disuruh" di samping kata "penyuruh" "orang yang menyuruh", maka dibentuk kata lain dengan beranalogi pada kata "penyuruh" itu (Arifin dan Junaiyah, 2009: 15).

\section{Kombinasi Proses}

Semua bentuk proses morfemis dapat berkombinasi sehingga ada bentuk seperti "perkeretaapian", "kemurahan hati, di-KEPRES-kan, ditilang, dan sebagainya. Lebih dari itu, proses pembentukan kata juga dapat dialami oleh frasa; maka terjadilah bentuk seperti "ketidakadilan", dipulauburukan" dan sebagainya (Arifin dan Junaiyah, 2009: 16).

\section{Proses Morfofonemik}

Morfofonemik merupakan perubahan fonem yang terjadi akibat proses pembubuhan afiks (Muslich 2010: 41). Selain pengertian tersebut, morfofonemik adalah proses pembentukan katakata dari satuan lain yang merupakan bentuk dasarnya. Abdul Chaer (2008: 42), berpendapat morfofonemik adalah kajian mengenai terjadinya perubahan bunyi atau perubahan fonem akibat dari adanya proses morfologi. Ketiga pendapat tersebut menyebutkan bahwa morfofonemik adalah gejala dalam afiksasi yang mengalami perubahan bunyi atau perubahan morfem.

Kridalaksana (2007: 184-185) berpendapat bahwa proses morfofonemik adalah peristiwa fonologis yang terjadi karena pertemuan morfem dengan morfem. Proses morfofonemik dalam bahasa Indonesia hanya terjadi dalam pertemuan realisasi morfem dasar (morfem bebas) dengan realisasi afiks (morfem terikat), baik prefiks, sufiks, infiks, konfiks maupun simulfiks.

Dalam pandangan Chaer (2007: 43-45), kaidah morfofonemik dalam bahasa Indonesia pada dasarnya sama dengan pembahasan yang diberikan oleh Kridalaksana. Namun, Abdul Chaer hanya memerikan proses morfofonemik ke dalam lima peristiwa, yaitu (a) pemunculan fonem; (b) pelesapan fonem; (c) peluluhan fonem; (d) perubahan fonem; (e) pergeseran fonem. Lebih lanjut, Chaer (2007: 43-45) menegaskan, sebagaimana tampak pada namanya, yang merupakan gabungan dari dua bidang studi yaitu morfologi dan fonologi, atau morfologi dan fonemik, bidang kajian morfofonologi atau morfofonemik biasanya dibahas dalam tataran morfologi tetapi sebenarnya lebih banyak menyangkut masalah fonologi. Kajian ini tidak dibicarakan dalam tataran fonologi karena masalahnya baru muncul dalam kajian morfologi, terutama dalam proses afiksasi, reduplikasi, dan komposisi. Masalah morfofonemik ini terdapat hampir di semua bahasa yang mengenal proses-proses morfologis. Dalam bahasa Indonesia ada beberapa jenis perubahan fonem berkenaan dengan proses morfologi ini, antara lain:

1. Pemunculan fonem, yakni munculnya fonem (bunyi) dalam proses morfologi yang pada mulanya tidak ada. Misalnya, dalam proses pengimbuhan prefiks "me- " pada dasar "baca" akan memunculkan bunyi sengau [m] yang semula tidak ada. Contoh, "me + baca” menjadi "membaca".

2. Pelesapan fonem, yakni hilangnya fonem dalam suatu proses morfologi. Misalnya, dalam proses pengimbuhan prefiks pada dasar "renang", maka bunyi [r] yang ada pada 
prefiks ber- dilesapkan. Juga, dalam proses pengimbuhan akhiran "wan" pada dasar "sejarah", maka fonem [h] pada dasar sejarah itu dilesapkan. Contoh; "ber + renang" menjadi -berenang" dan "sejarah + wan” menjadi "sejarawan".

3. Peluluhan fonem, yakni luluhnya sebuah fonem serta disenyawakan dengan fonem lain dalam suatu proses morfologi. Umpamanya, dalam pengimbuhan prefiks "me-" pada dasar "sikat", maka fonem /s/ pada kata sikat itu diluluhkan dan disenyawakan atau bisa dikatakan digantikan dengan fonem nasal /ny/ yang ada pada prefiks "me-" itu. Contoh; "me + sikat" menjadi "menyikat". Dalam proses peluluhan fonem juga terdapat beberapa syarat ketentuan, bahwa pada bentuk dasar yang diawali dengan konsonan [s] diluluhkan dengan nasal [ny], konsonan [k] diluluhkan dengan nasal [ng], konsonan [p] diluluhkan dengan nasal [m], dan konsonan [t] diluluhkan dengan nasal [n].

4. Perubahan fonem, yakni berubahnya sebuah fonem atau sebuah bunyi, sebagai akibat terjadinya proses morfologi. Umpamanya, dalam pengimbuan prefiks "ber-" pada dasar "ajar" terjadi perubahan bunyi, dimana fonem /r/ berubah menjadi fonem /1/. Perhatikan. "ber + ajar" menjadi "belajar".

5. Pergeseran fonem, yaitu berubahnya posisi sebuah fonem dari satu suku kata ke dalam suku kata yang lainnya. Umpamanya, dalam pengimbuhan sufiks "i" pada dasar "lompat", terjadi pergeseran dimana fonem /t/ yang semula berada pada suku kata "pat" menjadi berada pada suku kata "ti". Contoh, "lom-pat + i" menjadi "me-lom-pa-ti".

\section{PENUTUP}

Kata dalam bahasa Indonesia dapat tersusun oleh satu atau beberapa morfem. kata bermorfem satu disebut sebagai kata monomorfemis, sedangkan kata bermorfem lebih dari satu disebut kata polimorfemis. . Sebagai satuan gramatikal, morfem membentuk satuan yang lebih besar dan mempunyai makna. Sebagai satuan terkecil, morfem tidak dapat dipecah menjadi bagian-bagian yang lebih kecil, yang masing-masing bagian tersebut mengandung makna. Kata terkecil itu tersebut menyiratkan adanya satuan gramatikal yang lebih besar dari morfem. Inilah yang dalam ilmu bahasa disebut sebagai kata, frasa, klausa dan kalimat. dengan demikian, morfem menjadi bagian pembentuk atau konstituen satuan-satuan gramatikal yang lebih besar tersebut.

Pembentukan kata dalam bahasa Indonesia, dikenal dengan sebutan proses morfologis atau morfonemis. proses morfemis (morfological process) adalah suatu proses yang mengubah leksem menjadi kata. dapat dikatakan bahwa leksem merupakan input (masukan/ kata dasar), dan kata merupakan output (keluaran/hasil/turunan). Sehingga, proses morfemis juga disebut sebagai pembentukan kata. Sekurang-kurangnya, dalam bahasa Indonesia terdapat sembilan jenis proses morfemis. Antara lain; Derivasi Zero, Afiksasi, Reduplikasi, Komposisi, Abrevasi, Derivasi balik, Metanalisis, Analogi dan Kombinasi proses. Hubungan antara morfologi dan fonologi muncul pada sebuah proses morfofonemis. morfofonemik adalah kajian mengenai terjadinya perubahan bunyi atau perubahan fonem akibat dari adanya proses morfologi. 


\section{DAFTAR PUSTAKA}

Akmajian, Andrian et. al. 2001. Linguistics: An Introdution to Language and Communication. London: MIT Press.

Alisyahbana, Sutan Takdir. 1953. Tata Bahasa Baru Bahasa Indonesia II. Jakarta: Pustaka Rakyat.

Arifin, Zainal dan Junaiyah. 2009. Morfologi: Bentuk. Makna dan Fungsi Ed. II. Cet: III. Jakarta: Grasindo.

Bauer, Laurie. 1988. Introducing Linguistic Morphology. Great Britain: Edinburgh University Press.

Bloomfield, Leonard. 1984. Language. University of Chicago Editions. Chicago: University of Chicago Press.

Chaer, Abdul. 2009. Linguistik Umum. Jakarta: Rineka Cipta. . 2008. Morfologi Bahasa Indonesia; Pendekatan Proses. Jakarta: Rineka Cipta.

Francis, W. Nelson. 1958. The Structure of American English. New York: Ronald Press.

Ingguoe, Leksi S. Y. 1993. Tata Bahasa Rote. Yogyakarta: CV Budi Utama. 2015. Katamba, F. Morphology. London: The Macmillan Press Ltd.

Keraf, Gorys. 1989. Pembentukan Kata dalam Bahasa Indonesia. Jakarta: PT Gramedia.

Keraf, Gorys. 1991. Tata Bahasa Rujukan Bahasa Indonesia. Jakarta: Grasindo.

Kridalaksana, Harimurti. 1982. Kamus Linuistik. Jakarta: PT Gramedia.

.2007. Pembentukan Kata dalam BahasaIndonesia. Jakarta: PT Gramedia. 
Kushartanti, et al. 2007. Pesona Bahasa; Langkah Awal Memahami Linguistik. Jakarta: PT Gramedia Pustaka Utama.

M. Ramlan. 2009. Morfologi; Suatu Tinjauan Deskriptif Cet: 13. Yogyakarta: CV Karyono.

Muslich, Masnur. 2010. Tata Bentuk Bahasa Indonesia. Jakarta: Bumi Aksara.

Nura'isyah, Siti. 2014. Sekali Baca Langsung Inget: Kamus Detail Bahasa Indonesia. Jakarta: Niaga Swadaya.

Parera, Jos Daniel. 2007. Morfologi Bahasa. Jakarta: PT Gramedia Pustaka Utama.

Samsuri. 1982. Analisis Bahasa. Jakarta: Erlangga. 1988. Morfologi dan Pembentukan Kata. Jakarta: Dirjen Dikti Depdikbud.

Sapir, Edward. 1921. Language: An Introduction to the Study of Speech. San Diego. New York. London: Harcourt Brace Jovanovich. Publishers.

Simatupang, D. S. 1983. Reduplikasi Morfemis Bahasa Indonesia. Jakarta: Djambatan.

Suhardi. 2015. Dasar-Dasar Ilmu Semantik. Yogyakarta: Ar Ruzz Media.

Tukan, P. 2006. Mahir Berbahsa Indonesia 2. Jakarta: Yudhistira.

Wedhawati, et al. 2006. Tata Bahasa jawa Mutakhir. Yogyakarta: Kanisius.

Wibowo, Wahyu. 2003. Manajemen Bahasa; Pengorganisasian Karangan Prakmatik dalam Bahasa Indonesia untuk Mahasiswa dan Praktisi Bisnis. Jakarta: PT Gramedia Pustaka Utama.

Wiyanto, Agus. 2012. Kitab Bahasa Indonesia. Yogyakarta: Jogja Bangkit Publisher.

Zaim, M. 2014. Metode Penelitian Bahasa; Pendekatan Struktural. Padang: Sukabina Press. 